\title{
Magnetic Solid Phase Extraction of Trace Lead and Copper on Chromotrope FB Impregnated Magnetic Multiwalled Carbon Nanotubes From Cigarette and Hair Samples for Measurement by Flame AAS
}

\author{
Mustafa Soylak* and Zeliha Erbas \\ Erciyes University, Faculty of Sciences, Department of Chemistry, 38039 Kayseri, Turkey
}

\section{INTRODUCTION}

The levels of trace elements are an important component of safety and quality of the environment. Trace elements such as lead (Pb), arsenic (As), and cadmium (Cd) are generally recognized as pollutants and are harmful to the health of humans, plants, and animals (1-4). They are toxic when present in excessive amounts (5-8). Metals occur naturally in soil, plants, and air. However, their concentrations are usually increased due to anthropogenic activities such as from industry and traffic (9-12).

Lead is one of the toxic elements even at ultra-trace levels $(13,14)$ and is absorbed in humans through inhalation of air, dermal exposure, and ingestion of dust and soil. Other sources of lead are polluted water and lead-adulterated foods (15-18). Copper (Cu) is another critical, important and necessary trace element for humans, plants, and animals. It is an essential part of several enzymes, essential for human nutrition (19-20), and necessary for the synthesis of hemoglobin (2123). Consequently, an analytical method to preconcentrate, separate, and determine trace elements in environmental samples including natural waters is very important.

Classical solvent extraction, micellar extraction, flotation, coprecipitation and membrane filtration are popular separation-preconcentration methods for trace elements from environmental and food sam-

\footnotetext{
*Corresponding author.

e-mail: soylak@erciyes.edu.tr and

msoylak@gmail.com

Tel. E Fax: +90 3524374933
}

\begin{abstract}
A novel and simple magneticsolid phase extraction procedure for the separation-preconcentration of lead(II) and copper(II) at trace levels has been established by using Chromotrope FB impregnated magnetic multiwalled carbon nanotubes as a new adsorbent. The influences of critical analytical parameters like $\mathrm{pH}$, flow rates, eluent, and sample volume were optimized. Matrix effects were also examined. Analyte elements were quantitatively recovered at $\mathrm{pH}$ 6.0. The limit of detection values were $11.7 \mu \mathrm{g} \mathrm{L}^{-1}$ for lead and $3.7 \mu \mathrm{g} \mathrm{L}^{-1}$ for copper. The (\%) RSD values were generally found at $<7 \%$. The validation was performed by the analysis of NCS-DC73349 Bush Branches and Leaves certified reference material. The method was applied to the FAAS determination of lead and copper concentrations in cigarette and hair samples.
\end{abstract}

ples (24-28). Solid phase extraction is a popular separation-enrichment technique using novel nanomaterials with a high adsorption capacity and high surface area with resistivity to concentrated acids and bases (29-31).

In the present work, Chromotrope FB impregnated magnetic multiwalled carbon nanotubes have been used for the preconcentration -separation of $\mathrm{Pb}$ (II) and $\mathrm{Cu}$ (II) in hair and cigarette samples.

\section{EXPERIMENTAL}

\section{Instrumentation}

For this study, a Model 3110 flame atomic absorption spectrome- ter (PerkinElmer, Inc., Shelton, CT, USA) was used, equipped with air/acetylene flame with a $10 \mathrm{~cm}$ long slot burner head and hollow cathode lamps of $\mathrm{Cu}$ and $\mathrm{Pb}$. The the conditions for flame atomic absorption spectrometty (FAAS) are given in Table I. The calibration curve equations for $\mathrm{Cu}$ and $\mathrm{Pb}$ for FAAS determinations, respectively, were $(\mathrm{A}=0.0394 \mathrm{C}(\mathrm{Cu})+0.0056)$ and $(\mathrm{A}=0.0133 \mathrm{C}(\mathrm{Pb})+0.0011)$, where $\mathrm{A}$ is the absorbance and $\mathrm{C}$ is the concentration of the analyte. The correlation coefficients of the equations were 0.9992 and 0.99945 for $\mathrm{Cu}$ and $\mathrm{Pb}$, respectively.

The $\mathrm{pH}$ values were measured using a Sartorius PT-10 pH meter (Sartorius, Germany) with a glass electrode. A neodymium magnet was used for the phase separations. A vortex mixer (Wiggen Hauser, Malaysia) was used for thoroughly vortexing and mixing of the solutions.

\section{Solutions and Reagents}

Solutions were prepared with reverse osmosis purified water using a Milli- ${ }^{\circledR}{ }^{\circledR}$ system $18 \mathrm{M} \Omega-\mathrm{cm}$ resistivity (Millipore Corporation, USA). All chemicals were of reagent grade. Stock solutions of the analyte elements were prepared from their nitrates as $1000 \mu \mathrm{g} \mathrm{L}^{-1}$, solutions in $0.02 \mathrm{M} \mathrm{HNO}_{3}$. Multi-walled carbon nanotubes (MWNT) (Sigma no: 636614-2G) were purchased from Aldrich, Milwaukee, WI, USA. A solution of Chromotrope FB (\% 0.1 $\mathrm{m} / \mathrm{v}$ ) was prepared by dissolving of Chromo-trope FB No. B22328 (Alfa Aesar, Germany) in small amounts of ethanol and diluting to $50 \mathrm{~mL}$ with water. Certified reference material (CRM) NCS-DC73349 Bush 
TABLE I

FAAS Instrumental Parameters

\begin{tabular}{cccccc}
\hline Element & $\begin{array}{c}\text { Wavelength } \\
(\mathrm{nm})\end{array}$ & $\begin{array}{c}\text { Slit Width } \\
(\mathrm{nm})\end{array}$ & $\begin{array}{c}\text { Lamp Current } \\
(\mathrm{mA})\end{array}$ & \multicolumn{2}{c}{ Flame Conditions* } \\
$(\mathrm{a})$ & (b) \\
\hline $\mathrm{Cu}$ & 324.8 & 0.7 & 15 & 9.5 & 2.3 \\
$\mathrm{~Pb}$ & 283.3 & 0.7 & 15 & 9.5 & 2.3 \\
\hline
\end{tabular}

* (a) Air (L/min), (b) Acetylene (L/min).

Branches and Leaves (National Research Centre for Certified Reference Materials, Beijing, P.R. China) were used in the experiments for validation of the procedure.

Phosphate buffer solution ( 0.1 mol L-1) (pH 2.0-7.0), ammonia buffer solution $\left(0.1 \mathrm{~mol} \mathrm{~L}^{-1}\right)(\mathrm{pH}$ 8.0), and phosphate buffer solution $\left(0.1 \mathrm{~mol} \mathrm{~L}^{-1}\right)(\mathrm{pH} \mathrm{9.0)}$ were used in the experiments.

\section{Preparation of Chromotrope FB Impregnated Magnetic Multi- walled Carbon Nanotubes}

Magnetic multiwalled carbon nanotubes were obtained according to the procedure given in the literature (32) by using magnetite. To impregnate the Chromotrope FB to the surface of the magnetic multiwalled carbon nanotubes, $1.0 \mathrm{~g}$ magnetic multiwalled carbon nanotubes was added to $2 \mathrm{~mL}$ of Chromotrope FB solution and diluted to $30 \mathrm{~mL}$ with reverse osmosis water and stirring continuously for 20 minutes. Afterwards, the Chromotrope $\mathrm{FB} /$ magnetic multiwalled carbon nanotubes were filtered off, washed with reverse osmosis water, and dried overnight at 100 ${ }^{\circ} \mathrm{C}$. The amount of Chromotrope FB deposited on the magnetic multiwalled carbon nanotubes was estimated by UV-Vis spectrophotometry from the residual amount of a Chromotrope FB in the solution. It was found that $66 \%$ of Chromotrope $\mathrm{FB}$ was retained on the adsorbent.

\section{Test Procedure}

A 10-mL aqueous sample solution containing $\mathrm{Pb}$ (II) and $\mathrm{Cu}(\mathrm{II})$ was adjusted to $\mathrm{pH} 6.0$ using $2 \mathrm{~mL}$ tion. After 5 minutes, it was phosphate buffer solution. Then, $75 \mathrm{mg}$ of Chromotrope FB impregnated magnetic multiwalled carbon nanotubes were added to this soluvortexed with a revolution speed of $4000 \mathrm{rpm}$. After completion of the adsorption of the analytes onto the Chromotrope FB impregnated magnetic multiwalled carbon nanotubes, the adsorbent was separated at the bottom of the tube by using a neodymium magnet. The liquid phase was decanted. Then, $2 \mathrm{~mL}$ of $3.0 \mathrm{M} \mathrm{HNO}_{3}$ in $10 \%$ acetone was added to the adsorbent for desorption of the analyte ions. Then the Chromotrope FB impregnated magnetic multiwalled carbon nanotubes were separated from the sample by using a neodymium magnet. An amount of $100 \mu \mathrm{L}$ was aspirated into the nebulizer of the FAAS for absorbance measurements using the microinjection system.

\section{Analysis of CRM and Real Samples}

The method was also applied to CRM NCS DC73349 Bush Branches and Leaves, and cigarette and hair samples. A wet ash procedure was

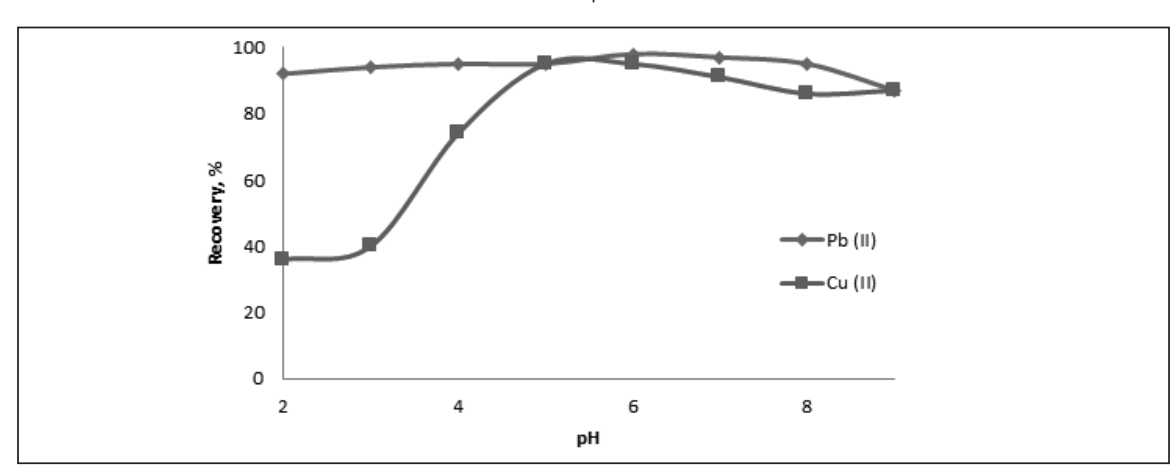

Fig. 1. Relation between $\mathrm{pH}$ and (\%) recovery for analyte ions. used for this purpose. One gram of a sample was transferred into a beaker and digested with $10 \mathrm{~mL}$ concentrated $\mathrm{HNO}_{3}$ for 15 minutes at room temperature, then placed on a hot plate at $95^{\circ} \mathrm{C}$ until a dry residue was obtained. The residue of each beaker was again digested with a mixture of $\mathrm{HNO}_{3}-\mathrm{H}_{2} \mathrm{O}_{2}(2: 1$ $\mathrm{v} / \mathrm{v})$ until dryness. The residues in the beakers were then dissolved in $15 \mathrm{~mL}$ distilled water and filtered with a Whatman blue band filter paper. Then the procedure given in the "Test Procedure" was applied to these samples.

\section{RESULTS AND DISCUSSION}

\section{Optimization}

The $\mathrm{pH}$ is an important factor affecting quantitative adsorption of the analytes in the extraction studies (33-38). The effects of the $\mathrm{pH}$ on the recoveries of $\mathrm{Pb}$ (II) and $\mathrm{Cu}(\mathrm{II})$ ions on the Chromotrope $\mathrm{FB}$ impregnated magnetic multiwalled carbon nanotubes were tested at the $\mathrm{pH}$ range of 2.0-9.0. The results are depicted in Figure 1. The recoveries of $\mathrm{Pb}$ (II) and $\mathrm{Cu}$ (II) were found to be quantitative in the $\mathrm{pH}$ range of 3.0-8.0 and 5.0-7.0, respectively. For all further work, $\mathrm{pH} 6.0$ was selected as optimal. The $\mathrm{pH}$ adjustments for $\mathrm{pH} 6.0$ were done by using phosphate buffer solution.

The amounts of Chromotrope FB impregnated magnetic multiwalled carbon nanotubes were also tested 
in the range of $25-100 \mathrm{mg}$. Quantitative recoveries for lead and copper ions were obtained in the range of 50-100 mg of magnetic adsorbent. An amount of $75 \mathrm{mg}$ Chromotrope FB impregnated magnetic

TABLE II

Effects of Various Eluents on the Recoveries of the Analytes (Volume of Eluent: $2 \mathrm{~mL} ; \mathrm{N}=3$ )

\begin{tabular}{|c|c|c|}
\hline \multirow[b]{2}{*}{ Eluent Type } & \multicolumn{2}{|c|}{ Recovery (\%) } \\
\hline & $\mathrm{Pb}(\mathrm{II})$ & $\mathrm{Cu}(\mathrm{II})$ \\
\hline $0.25 \mathrm{M} \mathrm{HNO}_{3}$ & $92 \pm 2$ & $81 \pm 4$ \\
\hline $0.5 \mathrm{M} \mathrm{HNO}_{3}$ & $96 \pm 3$ & $82 \pm 4$ \\
\hline $1.0 \mathrm{M} \mathrm{HNO}_{3}$ & $91 \pm 2$ & $84 \pm 3$ \\
\hline $2.0 \mathrm{M} \mathrm{HNO}_{3}$ & $94 \pm 1$ & $88 \pm 2$ \\
\hline $3.0 \mathrm{M} \mathrm{HNO}_{3}$ & $96 \pm 3$ & $90 \pm 1$ \\
\hline $0.25 \mathrm{M} \mathrm{HCl}$ & $87 \pm 3$ & $86 \pm 2$ \\
\hline $0.5 \mathrm{M} \mathrm{HCl}$ & $98 \pm 3$ & $91 \pm 3$ \\
\hline $1.0 \mathrm{M} \mathrm{HCl}$ & $95 \pm 4$ & $96 \pm 3$ \\
\hline $2.0 \mathrm{M} \mathrm{HCl}$ & $96 \pm 2$ & $90 \pm 1$ \\
\hline $3.0 \mathrm{M} \mathrm{HCl}$ & $94 \pm 1$ & $91 \pm 1$ \\
\hline $\begin{array}{c}0.25 \mathrm{~N} \mathrm{HNO}_{3} \\
\text { in } 10 \% \text { acetone }\end{array}$ & $63 \pm 2$ & $86 \pm 2$ \\
\hline $\begin{array}{c}0.5 \mathrm{M} \mathrm{HNO}_{3} \\
\text { in } 10 \% \text { acetone }\end{array}$ & $88 \pm 1$ & $88 \pm 1$ \\
\hline $\begin{array}{c}1.0 \mathrm{M} \mathrm{HNO}_{3} \\
\text { in } 10 \% \text { acetone }\end{array}$ & $94 \pm 1$ & $91 \pm 2$ \\
\hline $\begin{array}{c}2.0 \mathrm{M} \mathrm{HNO}_{3} \\
\text { in } 10 \% \text { acetone }\end{array}$ & $95 \pm 2$ & $94 \pm 2$ \\
\hline $\begin{array}{l}3.0 \mathrm{M} \mathrm{HNO}_{3} \\
\text { in } 10 \% \text { acetone }\end{array}$ & $97 \pm 1$ & $97 \pm 1$ \\
\hline
\end{tabular}

TABLE III

Effects of Some Matrix Ions on the Recoveries of $\mathrm{Pb}$ (II) and $\mathrm{Cu}$ (II) $(\mathbf{N}=3)$

\begin{tabular}{llccc}
\hline Ions & Added as: & $\begin{array}{c}\text { Recovery (\%) } \\
(\mu \mathrm{g} / \mathrm{mL})\end{array}$ & $\mathrm{Cb}(\mathrm{II})$ & \\
\hline $\mathrm{Na}^{+}$ & $\mathrm{NaNO}_{3}$ & 1000 & $97 \pm 0$ & $99 \pm 1$ \\
$\mathrm{~K}^{+}$ & $\mathrm{KCl}$ & 1000 & $97 \pm 1$ & $97 \pm 3$ \\
$\mathrm{SO}_{4}^{2-}$ & $\mathrm{Na}_{2} \mathrm{SO}_{4}$ & 2500 & $94 \pm 1$ & $95 \pm 2$ \\
$\mathrm{Fe}^{3+}$ & $\mathrm{Fe}\left(\mathrm{NO}_{3}\right)_{3} \cdot 9 \mathrm{H}_{2} \mathrm{O}$ & 5 & $91 \pm 2$ & $92 \pm 1$ \\
$\mathrm{Zn}^{2+}$ & $\mathrm{Zn}\left(\mathrm{NO}_{3}\right)_{2} \cdot 6 \mathrm{H}_{2} \mathrm{O}$ & 10 & $98 \pm 1$ & $100 \pm 2$ \\
$\mathrm{Mn}^{2+}$ & $\mathrm{Mn}\left(\mathrm{NO}_{3}\right)_{2} \cdot 4 \mathrm{H}_{2} \mathrm{O}$ & 10 & $100 \pm 2$ & $102 \pm 1$ \\
$\mathrm{Cu}^{2+}$ & $\mathrm{Cu}\left(\mathrm{NO}_{3}\right)_{2} \cdot 3 \mathrm{H}_{2} \mathrm{O}$ & 10 & $100 \pm 2$ & \\
$\mathrm{Mg}^{2+}$ & $\mathrm{Mg}\left(\mathrm{NO}_{3}\right)_{2} \cdot 6 \mathrm{H}_{2} \mathrm{O}$ & 100 & $102 \pm 0$ & $102 \pm 2$ \\
\hline
\end{tabular}

multiwalled carbon nanotubes was used for all other experiments.

The elution of the adsorbed analytes from the adsorbent is an important critical parameter (3843). Different eluent solutions (as )listed in Table II were used to elute the adsorbed analyte elements from the Chromotrope FB impregnated magnetic multiwalled carbon nanotubes. Quantitative recoveries for both analyte ions were obtained when $2.0 \mathrm{~mL}$ of $3.0 \mathrm{M} \mathrm{HNO}_{3}$ in $10 \%$ acetone was used as the eluent. For other elution solutions, the recovery of one analyte generally was quantitative; but the other ion was not recovered quantitatively. For all further studies, $2 \mathrm{~mL}$ of $3.0 \mathrm{M}$ $\mathrm{HNO}_{3}$ in $10 \%$ acetone was used as the eluent.

The volume of the samples is another key parameter for solid phase extraction studies to obtain a high preconcentration factor (4449). The effects of the sample volume on the recoveries were examined by using $10-40 \mathrm{~mL}$. The recoveries were quantitative for both $\mathrm{Cu}$ and $\mathrm{Pb}$ in the range of 10-30 $\mathrm{mL}$. The recovery values were not quantitative for sample volumes higher than $30 \mathrm{~mL}$. The preconcentration factor was 30 with a final volume of $2 \mathrm{~mL}$.

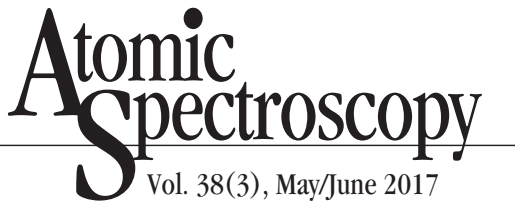

\section{Matrix Effects}

The negative and/or positive effects of alkali, alkaline earth metals, and some metal ions at high concentrations in real samples are a big problem in the determination of trace metals (50-56). The influences of matrix components were investigated, and the results are listed in Table III. The model solution containing analyte elements and matrix components were prepared and then applied to the developed procedure as described in the Experimental section. The results clearly demonstrate that the interfering ions did not interfere with the recovery values of the analyte elements, and that the proposed method was fairly free from matrix components as given in Table III.

\section{Analytical Features}

The detection limits (LODs) of the present method for lead and copper, calculated based on 11 determinations of the standard deviation of the blank, were $11.7 \mu \mathrm{g} \mathrm{L}^{-1}$ and $3.7 \mu \mathrm{g} \mathrm{L}^{-1}$, respectively. The relative standard deviation (RSD) determined from 11 analyses was below 5\%.

\section{Application to CRM Sample}

The present method was applied to CRM NCS-DC73349 Bush Branches and Leaves to verify the validity of the method for copper and lead levels after the wet digestion procedure as given in the Experimental section. The results in Table IV show that the presented solid phase extraction method is in good agreement with the certified values of the certified reference material.

The correctness of the present procedure was also verified by analyzing the concentration after addition of known amounts of $\mathrm{Cu}$ and $\mathrm{Pb}$ onto a cigarette and a hair sample. The results listed in Table $\mathrm{V}$ for the cigarette sample and in Table 
VI for the hair sample show that good agreement was obtained between the added and found analyte content using the present solid phase extraction system.

In addition, the analyte elements of $\mathrm{Cu}$ and $\mathrm{Pb}$ in cigarette samples (purchased at a local market in Kayseri, Turkey) and in hair samples

TABLE IV

Application of Present Method to CRM NCS-DC73349 Bush Branches and Leaves for the Determination of $\mathrm{Pb}$ and $\mathrm{Cu}$ $(\mathbf{N}=3)$

\begin{tabular}{lll}
\hline & Lead & Copper \\
\hline Certified & & \\
value $(\mu \mathrm{g} / \mathrm{g})$ & 47 & 6.6 \\
Found $(\mu \mathrm{g} / \mathrm{g})$ & $45.2 \pm 3.0$ & $6.1 \pm 0.8$ \\
Recovery $(\%)$ & 96 & 93 \\
\hline
\end{tabular}

TABLE V

Addition-Recovery Tests for Cigarette Sample ( $N=3)$ Using Solid Phase Extraction

\begin{tabular}{cccc}
\hline & $\begin{array}{c}\text { Added } \\
(\mu \mathrm{g})\end{array}$ & $\begin{array}{c}\text { Found } \\
(\mu \mathrm{g})\end{array}$ & $\begin{array}{c}\text { Recovery } \\
(\%)\end{array}$ \\
\hline $\mathrm{Pb}$ & 0 & $1.14 \pm 0$ & \\
& 4 & $5.2 \pm 0.3$ & 95 \\
& 8 & $8.8 \pm 0.3$ & 95 \\
$\mathrm{Cu}$ & 0 & $3.0 \pm 0.1$ & \\
& 2 & $5.1 \pm 0.2$ & 102 \\
& 4 & $7.0 \pm 1.0$ & 98 \\
\hline
\end{tabular}

TABLE VI

Addition-Recovery Tests for Hair Sample $(\mathrm{N}=3)$ Using Solid Phase Extraction

\begin{tabular}{cccc}
\hline & $\begin{array}{c}\text { Added } \\
(\mu \mathrm{g})\end{array}$ & $\begin{array}{c}\text { Found } \\
(\mu \mathrm{g})\end{array}$ & $\begin{array}{c}\text { Recovery } \\
(\%)\end{array}$ \\
\hline $\mathrm{Pb}$ & 0 & 0 & \\
& 16 & $15.2 \pm 2$ & 95 \\
& 24 & $22.7 \pm 1$ & 94 \\
$\mathrm{Cu}$ & 0 & $0.4 \pm 0.1$ & \\
& 8 & $8.2 \pm 0.1$ & 97 \\
& 12 & $12.2 \pm 1$ & 98 \\
\hline
\end{tabular}

(from healthy subjects living in Kayseri, Turkey) were determined by flame atomic absorption spectrometry. The results are listed in Table VII.

\section{Comparison of Proposed Proce- dure With Preconcentration Methods in Literature}

A comparison between the figures of merit of the proposed method with other solid phase extraction methods used for the preconcentration/separation of copper and lead is given in Table VIII (55-62).

TABLE VII

Application of Present Procedure Using Flame AAS Analysis of Cigarette and Hair Samples (N=3)

\begin{tabular}{lcc}
\hline Sample & \multicolumn{2}{c}{ Concentration $(\mu \mathrm{g} / \mathrm{g})$} \\
& $\mathrm{Pb}$ & $\mathrm{Cu}$ \\
\hline Cigarette 2 & $\mathrm{BDL}$ & $13.2 \pm 0.3$ \\
Cigarette 3 & $\mathrm{BDL}$ & $7.7 \pm 0.1$ \\
Cigarette 1 & $\mathrm{BDL}$ & $10.2 \pm 0.4$ \\
Hair 2 & $\mathrm{BDL}$ & $14.6 \pm 1.0$ \\
Hair 3 & $\mathrm{BDL}$ & $5.8 \pm 1.0$ \\
\hline
\end{tabular}

BDL: below the detection limit.

\section{CONCLUSION}

A simple and novel procedure based on magnetic solid phase extraction of lead and copper at trace levels on Chromotrope FB impregnated magnetic multiwalled carbon nanotubes in hair and cigarette samples from Kayseri, Turkey, has been established. The advantages of the presented magnetic solid phase extraction method include time savings for adsorption and elution steps, low use of use of organic solvents, and the magnetic adsorbent can be used at least five times without loss of its adsorption properties.

Received November 8, 2016.

\section{REFERENCES}

1. X. H. Zhu, S. S. Lyu, P. P. Zhang, X G. Chen, D. D. Wu, and Y. Ye, Environ. Earth. Sci. 75, 98 (2016). DOI 10.1007/s12665-015-5036-9

2. S. Saracoglu, U. Divrikli, M. Soylak, L. Elci, and M. Dogan, J. Trace Microprobe Techn. 21, 389 (2003).

3. G. Guleryuz, M. Arslan, B. Izgi, and S. Gucer, Z. Naturforsch. C 61, 357 (2006).

4. O. Turkoglu, S. Saracoglu, M. Soylak, and L. Elci, Trace Elem. Electroly. 21, 4 (2004)
TABLE VIII

Comparison of Proposed Method

With Some Methods in the Literature

\begin{tabular}{|c|c|c|c|}
\hline Adsorbent & $\mathrm{PF}^{\mathrm{a}}$ & $\mathrm{LOD}^{\mathrm{b}}(\mu \mathrm{g} / \mathrm{L})$ & Ref. \\
\hline $\begin{array}{l}\text { Magnetic allylamine modified } \\
\text { graphene oxide-poly(vinyl acetate-co- } \\
\text { divinylbenzene) nanocomposite }\end{array}$ & 40 & $\mathrm{~Pb}: 2.39, \mathrm{Cu}: 2.34$ & 32 \\
\hline $\mathrm{Fe}_{3} \mathrm{O}_{4} /$ graphene magnetic nanoparticles & - & $\mathrm{Pb}: 0.87, \mathrm{Cu}: 0.22$ & 42 \\
\hline Core-Shell magnetic chitosan biopolymer & 25 & - & 52 \\
\hline Oxidized single-walled carbon nanotubes & 50 & Pb:5.4, Cu: 3.9 & 57 \\
\hline Multiwalled carbon nanotubes & 50 & $\mathrm{~Pb}: 5.5, \mathrm{Cu}: 2.3$ & 58 \\
\hline $\begin{array}{l}\text { Chromotrope FB impregnated magnetic } \\
\text { multiwalled carbon nanotubes }\end{array}$ & 15 & Pb: 11.7, Cu: 3.7 & $\begin{array}{l}\text { This } \\
\text { work }\end{array}$ \\
\hline
\end{tabular}


5. D.R. Chettle, J. Radioanal. Nucl. Ch. 268, 653 (2006).

6. D. Mendil, O.F. Unal, M. Tuzen, and M. Soylak, Food Chem. Toxicol. 48, 1383 (2010).

7. E. Chirila, S. Dobrinas, and V. Coatu, Rev. Chim-Bucharest. 55, 381 (2004).

8. N. Alkan, A. Alkan, K. Gedik, and A. Fisher, Toxicol. Ind. Health 32, 447 (2016).

9. S. Savasci, and M. Akcay, Turk. J. Chem. 20, 146 (1996).

10. F. Sipahi, and S. Uslu, Arab. J. Geosci. 9, 600 (2016). DOI 10.1007/s12517-016-2620-6

11. R. Mehra, and M. Juneja, J. Ind. Chem. Soc. 81, 349 (2004).

12. N. Shaheen, N. Md. Irfan, I. N. Khan, S. Islam, Md. S. Islam, and Md.K. Ahmed, Chemosphere 152, 431 (2016).

13. F. Yalcin, S. Kilic, D. G. Nyamsari, M. G. Yalcin, and M. Kilic, Pol. J. Environ. Stud. 25, 471 (2016).

14. U. Divrikli, A. A. Kartal, M. Soylak, and L. Elci, J. Hazard. Mater. 145, 459 (2007).

15. D. S. Herman, M. Geraldine, C. C. Scott, and T. Venkatesh, Toxicol. Ind. Health 22, 249 (2006).

16. L. Vilizzi, and A.S. Tarkan, Environ. Monit. Assess. 188, 243 (2016). DOI 10.1007/s10661-016-5248-9

17. A. X. Wang, L. P. Guo, and D. M. Wu, Spectrosc. Spect. Anal. 26, 1345 (2006).

18 M. Tuzen, S. Saracoglu, and M. Soylak, J. Food Nutr. Res. 47, 120 (2008).

19. J. Semancikova, and D. Remeteiova, Holist. Approach Environ. 6, 55 (2016).

20. M. Tuzen, M. Soylak, D. Citak, H.S. Ferreira, M.G.A. Korn, and M.A. Bezerra, J. Hazard. Mater. 162, 1041 (2009).

21. M. Stanek, W. Andrzejewski, J. Mazurkiewicz, B. Janicki, D. CyganSzczegielniak, A. Roślewska, K. Stasiak, and I. Waszak, Pol. J. Environ. Stud. 25, 301 (2016).

22. M. Ghaedi, R. Shabani, M. Montazerozohori, A. Shokrollahi, A. Sahraiean, H. Hossainian, and M. Soylak, Environ. Monit. Assess.
174, 171 (2011).

23. E. Pip, Environ. Health Persp. 108, 863 (2000).

24. M. Tuzen, and M. Soylak, J. Hazard. Mater. 162, 724 (2009).

25. T. Stafilov, G. Pavlovska, and K. Cundeva, Turk. J. Chem. 24, 303 (2000).

26. A. Shokrollahi, M. Ghaedi, O. Hossaini, N. Khanjari, and M. Soylak, J. Hazard. Mater. 160, 435 (2008).

27. N. Ashouri, A. Mohammadi, R. Hajiaghaee, M. Shekarchi, and M.R. Khoshayan, Desalin. Water Treat. 57, 14280 (2016).

28. S. Saracoglu, M. Soylak, D. Cabuk, Z. Topalak, and Y. Karagozlu, J. AOAC Int. 95, 892 (2012).

29. C.Q. Tu, and X.R. Wen, J. Chinese Chem. Soc. 57, 356 (2010).

30. S.G. Ozcan, N. Satiroglu, and M. Soylak, Food Chem. Toxicol. 48, 2401 (2010).

31. F. Raoufi, S. Bagheri, P. Nasehi, E. Niknam, K. Niknam, and H.R. Farmani, Orient. J. Chem. 32, 575 (2016).

32. M. Khan, E. Yilmaz, B. Sevinc, E. Sahmetlioglu, J. Shah, M.R. Jan, and M. Soylak, Talanta 146, 130 (2016).

33. E. Aliyari, M. Alvand, and F. Shemirani, RSC Adv. 6, 64193 (2016).

34. R. Gao, and Z. Fan, At. Spectrosc. 37, 195 (2016).

35. X. Lopez, and V.M. Castano, J. Nanosci. Nanotechn. 8, 5733 (2008).

36. M. Soylak, L. Elci, and M. Dogan, Anal. Lett. 26, 1997 (1993)

37. E. Ghorbani-Kalhor, Microchim. Acta 183, 2639 (2016).

38. H.M. Marwani, A.E. Alsafrani, H.A. Al-Turaif, A.M. Asiri, and S.B. Khan, Bull. Mater. Sci. 39, 1011 (2016).

39. M. Soylak, Y.E. Unsal, N. Kizil, and A. Aydin, Food. Chem. Toxicol. 48, 517 (2010).

40. S.Z. Mohammadi, and A. Seyedi, Toxicol. Environ. Chem. 98, 705 (2016).

41. F.A. Aydin, and M. Soylak, J. Hazard. Mater. 173, 669 (2010).

42. Q. Yin, Y. Zhu, S. Ju, W. Liao, and Y. Yang, Res. Chem. Intermed. 42, 4985 (2016).

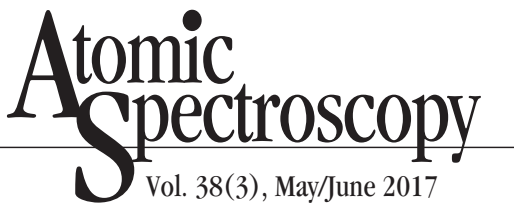

43. J.P.R. da Silva, G.F.B. Cruz, R.J. Cassella, and W.F. Pacheco, Quim. Nova, 39, 561 (2016).

44. M. Soylak, Anal. Lett. 37, 1203 (2004).

45. M. Roushani, Y.M. Baghelani, S. Abbasi, S.Z. Mohammadi, M. Zahedifar, and M. Mavaei, Commun. Soil. Sci. Plan. Anal. 47, 1207 (2016).

46. C. Duran, V.N. Bulut, D. Ozdes, A. Gundogdu, and M. Soylak, J. AOAC Int. 92, 257 (2009).

47. N. Khorshidi, and A. Niazi, Separ. Sci. Technol. 51, 1675 (2016).

48. M. Soylak, Fresen. Environ. Bull. 7, 383 (1998).

49. M. Khajeh, F. Saravani, M. GhaffariMoghaddam, and M. Bohlooli, Int. J. Vegetable Sci. 22, 266 (2016).

50. C. Maiti, R. Banerjee, and S. Maiti, D. Dhara, Des. Monomers. Polym. 19, 669 (2016).

51. B. Bitirmis, D. Trak, Y. Arslan, and E. Kenduzler, Anal. Sci. 32, 667 (2016).

52. M.H. Beyki, S. Miri, F. Shemirani, M. Bayat, and P.R. Ranjbar, Clean- Soil Air Soil Water 44, 710 (2016).

53. Z.A. AL Othman, E. Yilmaz, M. Habila, and M. Soylak, Desalin. Water Treat. 51, 6770 (2013).

54. S. Procházková, and R. Halko, Anal. Lett. 49, 1656 (2016).

55. M.H. Beyki, S. Miri, F. Shemirani, M. Bayat, and P.R. Ranjbar, Clean- Soil Air Soil Water 44, 710 (2016).

56. M. Soylak, and N. Kizil, At. Spectrosc. 34, 216 (2013).

57. S. Chen, C. Liu, M. Yang, D. Lu, L. Zhu, and Z. Wang, J. Hazard. Mater. 170, 247 (2009).

58. E. Yilmaz, and M. Soylak, Environ. Monit. Assess. 186, 5461 (2014).

59. M. Soylak, I. Narin, L. Elci, and M. Dogan, Kuwait J. Sci. Eng. 28, 361 (2001).

60. M. Soylak, and E. Yilmaz, Desalination 275, 297 (2011).

61. S. Saracoglu, M. Soylak, and L. Elci, Trace Elem. Electroly. 18, 129 (2001).

62. M. Ghaedi, M. Montazerozohori, F. Marahel, M.N. Biyareh, and M. Soylak, Chinese J. Chem. 29, 2141 (2011). 